\title{
Simulations of tropical rainforest albedo: is canopy wetness important?
}

\author{
SILVIA N.M. YANAGI ${ }^{1}$ and MARCOS H. $\operatorname{COSTA}^{2}$ \\ ${ }^{1}$ Departamento de Engenharia, Universidade Federal de Lavras, Caixa Postal 3037, 37200-000 Lavras, MG, Brasil \\ ${ }^{2}$ Universidade Federal de Viçosa, Departamento de Engenharia Agrícola, \\ Av. P.H. Rolfs, s/n, 36570-000 Viçosa, MG, Brasil
}

Manuscript received on October 14, 2009; accepted for publication on March 1, 2011

\begin{abstract}
Accurate information on surface albedo is essential for climate modelling, especially for regions such as Amazonia, where the response of the regional atmospheric circulation to the changes on surface albedo is strong. Previous studies have indicated that models are still unable to correctly reproduce details of the seasonal variation of surface albedo. Therefore, it was investigated the role of canopy wetness on the simulated albedo of a tropical rainforest by modifying the IBIS canopy radiation transfer code to incorporate the effects of canopy wetness on the vegetation reflectance. In this study, simulations were run using three versions of the land surface/ecosystem model IBIS: the standard version, the same version recalibrated to fit the data of albedo on tropical rainforests and a modified version that incorporates the effects of canopy wetness on surface albedo, for three sites in the Amazon forest at hourly and monthly scales. The results demonstrated that, at the hourly time scale, the incorporation of canopy wetness on the calculations of radiative transfer substantially improves the simulations results, whereas at the monthly scale these changes do not substantially modify the simulated albedo.
\end{abstract}

Key words: canopy wetness, diurnal albedo, tropical forest and simulation.

\section{INTRODUCTION}

Surface albedo is the main factor that affects the land radiation balance not only controlling the amount of solar energy available for heating the ground and lower atmosphere and for evaporating water (Rowe 1991), but also affecting the atmospheric circulation and climate. Particularly in the tropics, where the solar radiation balance is stronger, changes in surface albedo have been found to influence the regional climate, as studies on tropical deforestation demonstrate (Nobre et al. 1991, Dirmeyer and Shukla 1994, Costa and Foley 2000). An accurate simulation of the solar radiation balance is also important. For example, Berbet and Costa (2003) demonstrated that an uncertainty of $10 \mathrm{~W} \cdot \mathrm{m}^{-2}$ in the seasonal solar radiation balance translates into an uncertainty of $30 \mathrm{~mm} / \mathrm{month}$ in the simulated rainfall, which

Correspondence to: Silvia Nazaré Monteiro Yanagi

E-mail: snmonteiro@yahoo.com.br is very significant especially in the dry season of that region. In this context, a good representation of albedo by climate models is essential to correctly address the problem of changing the tropical deforestation climate.

However, Berbet and Costa (2003) also verified that even a complex, state-of-the-art, land surface scheme coupled to a climate model is unable to correctly reproduce details of the seasonal variability of the albedo of tropical rainforests, although it reproduces well the annual mean and some aspects of the seasonal variability. This indicates that there is still much to be learned - and incorporated into models - about the sources of variation of the albedo at both hourly and monthly time scales.

At the monthly time scale, Culf et al. (1995) analyzed the surface albedo at forest sites in Amazonia. The authors reported that the albedo seasonality at these sites is not related to changes on the solar elevation angle nor to cloudiness, but suggested a relationship with soil 
moisture. Although soil moisture affects ground albedo, changes in the forest albedo are most likely related to soil moisture-correlated variables: smaller soil exposure, darker leaves (associated with the leaf water potential) and higher canopy wetness (Berbet and Costa 2003). Canopy wetness, in particular, is a strong candidate for changing canopy albedo because the reflectance of liquid water varies depending on the wavelength, between $0-5 \%$, much lower than the $12-13 \%$ usually measured above tropical rainforest canopies. Hence the presence of liquid water on the canopy increases the absorption of solar radiation, reducing the canopy overall albedo.

Here, we investigated the role of canopy wetness in the simulated albedo of a tropical rainforest. In this study we have run simulations using three versions of the land surface/ecosystem model IBIS: the standard version with the original calibration used by Delire and Foley (1999), the same version recalibrated to fit the data of albedo on tropical rainforests, and a modified version that incorporates the effects of canopy wetness on calculated surface albedo. The next section describes the sites and instrumentation that measured the albedo data used here to validate the model simulations. Sections 3 and 4 describe the IBIS model, the modifications to incorporate canopy wetness and the experiment design, whereas Section 5 presents and discusses the simulation results.

\section{SITES, INSTRUMENTATION AND DATA}

Field data used in this paper were measured at three sites in the Amazon during the ABRACOS (Anglo Brazilian Amazonian Climate Observation Study) and LBA projects (Large-Scale Biosphere-Atmosphere Experiment in Amazonia). Ducke and Cuieiras (K34) Reserves are reserves of forest protected by INPA (Instituto Nacional de Pesquisas da Amazônia) located about $25 \mathrm{~km}$ northeast and $70 \mathrm{~km}$ north of Manaus, respectively. These sites are surrounded by undisturbed forests for at least $5 \mathrm{~km}$. Jaru Reserve is an IBAMA (Instituto Brasileiro do Meio Ambiente e dos Recursos Naturais Renováveis) forest reserve and is located about $80 \mathrm{~km}$ north of Ji-Paraná (Fig. 1).

At the Cuieiras Reserve a piranometer (Kipp \& Zonen, Delft, Netherlands), connected on a datalogger

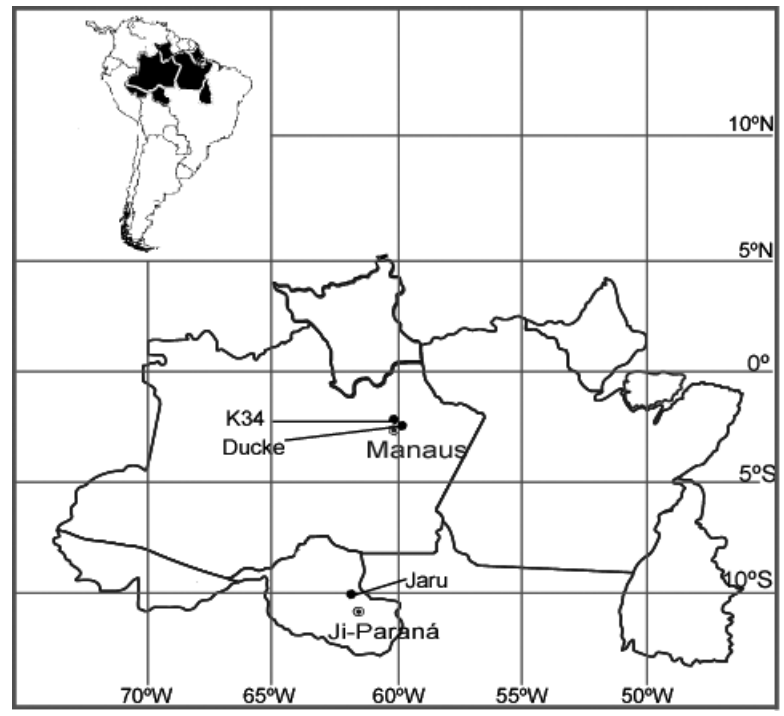

Fig. 1 - Location of study sites.

model (21X, Campbell Scientific) measured incident and reflected solar radiations at each minute, storing the averages at every 20 minutes. For the remaining sites, incident and reflected solar radiations were measured using two solarimeters (Kipp and Zonen, Delft, the Netherlands). These instruments are part of an automatic weather station (Didcot Instruments, Abingdon, UK) connected to a datalogger (CR10, Campbell Scientific, Shepshed, UK), and hourly-averaged data were recorded.

We used incident and reflected solar radiations and precipitation data collected from June 1999 to September 2000 at Cuieiras Reserve, from January to December 1995 at Ducke Reserve, and from January to December 1993 at Jaru Reserve. Data used in this study are available on-line through www.cptec.inpe.br/abracos/available.html and http://lba.cptec.inpe.br/beija-flor.

\section{DESCRIPTION OF THE IBIS MODEL}

To simulate the diurnal albedo of an Amazon tropical forest we used the Integrated Biosphere Simulator-IBIS (Foley et al. 1996). It includes representations of land surface processes, like energy, water and momentum exchange among the soil-vegetation-atmosphere system, canopy physiology, vegetation phenology, vegetation dynamics and terrestrial carbon balance. Originally, IBIS was globally calibrated (more details in Delire and Foley 1999, Kucharik et al. 2000), and since then it has been 
used in several studies of the biosphere-atmosphere interactions in Amazonia (Costa and Foley 2000, Botta and Foley 2002, Foley et al. 2002, Berbet and Costa 2003).

One of the processes simulated by IBIS and specially important in this study is the exchange of solar radiation among the soil-vegetation-atmosphere system. Solar radiation transfer is calculated following the twostream approximation, with separate calculations for direct and diffuse radiations in both visible and nearinfrared bands. The canopy radiative transfer code of IBIS is standard in the literature (Norman and Jarvis 1975, Sellers 1985, Sellers et al. 1986, Pollard and Thompson 1995, Bonan 1996, Oleson et al. 2004). In this study we modified the IBIS canopy radiation transfer code to incorporate the effects of canopy wetness on the vegetation reflectance. Although IBIS also calculates the canopy wetness, in this work the parameters $\omega$ (scattering coefficient, eq. 3 in Sellers 1985; eq. 11 in Sellers et al. 1986; eq. 3.5 in Oleson et al. 2004), $\beta$ (upscatter parameter for diffuse radiation, eq. 3 in Sellers 1985; eq. 11 in Sellers et al. 1986; eq. 3.6 in Oleson et al. 2004) and $\beta_{o}$ (upscatter parameter for direct radiation, eq. 4 in Sellers 1985; eq. 12 in Sellers et al. 1986; eq. 3.7 in Oleson et al. 2004) are modified to include the radiative effects of canopy wetness, according to Equations 1 to 4:

$$
\begin{aligned}
& \omega=\omega^{d r y} \cdot\left(1-f_{\text {wet }}\right)+\omega^{\text {water }} \cdot f_{\text {water }} \\
& +\omega^{\text {snow }} \cdot f_{\text {snow }} \\
& \beta=\omega^{d r y} \cdot \beta^{d r y}\left(1-f_{\text {wet }}\right)+\omega^{\text {water }} \cdot \beta^{\text {water }} \cdot f_{\text {water }} \\
& +\omega^{\text {snow }} \cdot \beta^{\text {snow }} \cdot f_{\text {snow }} / \omega \\
& \beta_{o}=\omega^{d r y} \cdot \beta_{o}^{d r y}\left(1-f_{\text {wet }}\right)+\omega^{\text {water }} \cdot \beta_{o}^{\text {water }} \cdot f_{\text {water }} \\
& +\omega^{\text {snow }} \cdot \beta_{o}^{\text {snow }} \cdot f_{\text {snow }} / \omega \\
& \omega^{\text {water }}=v \cdot \omega^{d r y}
\end{aligned}
$$

where $f_{\text {wet }}$ is the total wet (water and snow) fraction of the canopy $\left(f_{\text {wet }}=f_{\text {water }}+f_{\text {snow }}\right), f_{\text {water }}$ is the fraction of the canopy wet by liquid water, and $f_{\text {snow }}$ is the fraction of the canopy wet by snow. The superscripts dry, water and snow denote dry, wet by water and wet by snow canopies, respectively. $v$ is the ratio of the scattering coefficients of the canopy surfaces wet by water and dry canopy surfaces individually applied to leaves and stems.

\section{EXPERIMENT DESIGN}

In this study we conducted three simulations of the diurnal surface albedo for each of the three Amazon forest sites using the off-line IBIS version, as follows:

1) DF99: for reference to previous studies, this simulation uses the set of optical parameters used by Delire and Foley (1999);

2) $\mathrm{DC}_{i}$, the dry-canopy (control) simulations: use the original code without modifications to incorporate the effects of wetness on canopy reflectance, and a set of leaf optical parameters to better fit the simulated results to the experimental data of the studied sites, minimizing the RMSE between the observed and simulated albedos. The subscript $i$ may be equal to $M$ for the Manaus-nearby sites (Ducke and Cueiras Reserves), or $J$ for Jaru Reserve.

3) $\mathrm{WC}_{i}$, the wet-canopy simulations: similar to $\mathrm{DC}_{i}$, but including the modifications described in Equations (1) through (4).

The terms dry-canopy (DC) and wet-canopy (WC), when referring to versions of the IBIS code, denote only the status of the canopy during the radiative transfer calculations. It should be noted that both versions simulate the interception of water by the canopy, and the evaporation and dripping of the canopy-stored water.

To calibrate the DC simulations, we initially performed a sensitivity analysis of the simulated albedo to several optical parameters of the canopy. The most sensitive parameters are the upper and lower canopy leaf orientation ( $\chi_{\text {leaf-up }}$ and $\chi_{\text {leaf-lo }}$, respectively), and upper and lower canopy visible and near-infrared (NIR) leaf reflectance $\left(\alpha_{\text {VIS-up }}^{\text {Leaf }}, \alpha_{\text {VIS-lo }}^{\text {Leaf }}, \alpha_{\text {NIR-up }}^{\text {Leaf }}\right.$ and $\alpha_{\text {NIR-lo }}^{\text {Leaf }}$, respectively). The model is run several times with different combinations of the parameters above. Table I shows, for the DC simulations, the parameter combinations that provide the best adjustment of the diurnal albedo without considering the effect of canopy wetness. Next, this set of parameters is added to the WC version of the code, and the parameters $f_{\text {wetmax }}$ (maximum fraction of water cover on two-sided leaf), $\tau_{d r i p}$ (decay time for intercepted liquid drip off) and $v$ (ratio of the scattering coefficients of the canopy surfaces wet 

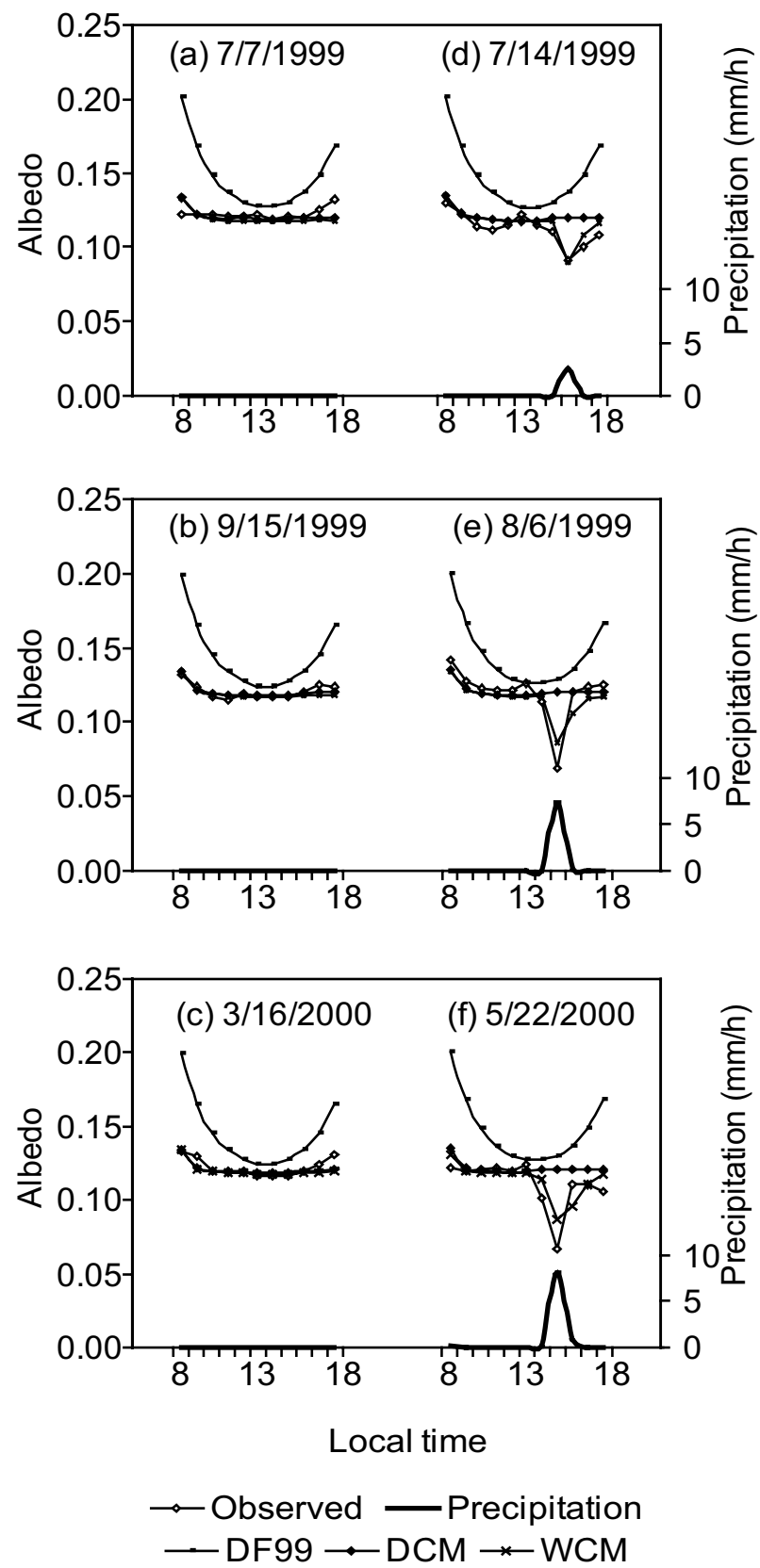

Fig. 2 - Diurnal variation of the simulated and observed surface albedo in the Cuieiras Reserve for the selected days.

by water and dry canopy surfaces individually applied to leaves and stems) are calibrated.

\section{RESULTS AND DISCUSSION}

The three IBIS versions are run for each of the three sites. Figures 2 to 4 show the diurnal profile of the surface albedo for Cuieiras, Ducke and Jaru Reserves, respectively, for selected days of the year. To facilitate the interpretation, the selected days represent either no-rain days - charts on the left side $(a, b, c)$ of the figures or days with a single daytime rainfall event - right side (d, e, f) of the figures. Figures 2 and 3 show results for the Manaus $(M)$ set of parameters, while Figure 4 shows results for the Jaru $(J)$ set of parameters, according to Table I.

The DF99 simulations overestimate the surface albedo, particularly when the zenith angle is high (Figs. 2 to 4 ). The albedo simulated by the calibrated model 

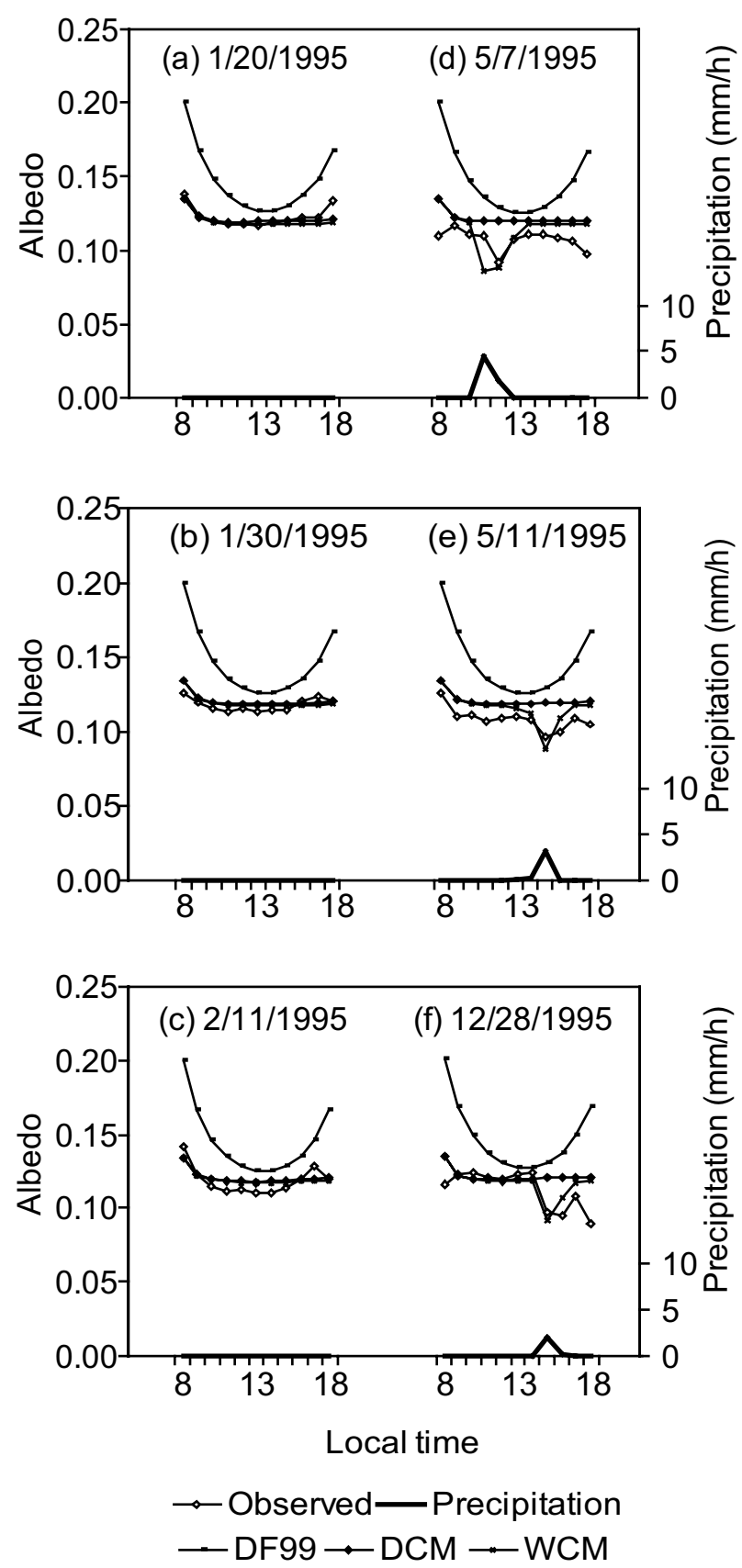

Fig. 3 - Diurnal variation of the simulated and observed surface albedo in the Ducke Reserve for the selected days.

$\left(\mathrm{DC}_{M}\right.$ and $\left.\mathrm{DC}_{J}\right)$ fit better to the observed data in days without precipitation occurrence (left side of Figs. 2 to 4), but the DC version of the model does not represent the observed albedo drop during precipitation events (right side of Figs. 2 to 4 ).

However, WC simulations show that the modified version of IBIS is able to reproduce the considerable decrease in surface albedo during precipitation hours (right side of Figs. 2 to 4). This reduction in the surface albedo is consistent with an increase of the absorption of the incident solar radiation by the liquid water deposited on the leaves, increasing solar radiation absortance and reducing solar radiation reflectance.

Table II shows the statistics of observed and simulated surface albedos for the precipitation hours and for the entire time series at three sites in the Amazon rain- 
TABLE I

Optical parameters used by the DF99 calibration and new calibrations using the dry-canopy (DC $i$ ) and wet-canopy $\left(\mathbf{W C}_{i}\right)$ versions of the model, where $i$ is equal to $M$ for the Manaus-nearby sites (Ducke and Cueiras Reserves) or $J$ for the Jaru Reserve. $\chi_{l e a f-l o}$ and $\chi_{l e a f-u p}$ are the upper and lower canopy leaf orientations, $\alpha_{\text {Vis-lo }}^{\text {Leaf }}$ and $\alpha_{\text {Vis-up }}^{\text {Leaf }}$ are the lower and upper visible leaf reflectances of canopy, $\alpha_{N I R-l o}^{\text {Leaf }}$ and $\alpha_{N I R-u p}^{\text {Leaf }}$ are the lower and upper canopy NIR leaf reflectances, $f_{\text {wetmax }}$ is maximum fraction of water cover on two-sided leaf, $\tau_{\text {drip }}$ is the decay time for intercepted liquid drip off, and $v$ is the ratio of the scattering coefficients of the canopy surfaces wet by water and dry canopy surfaces individually applied to leaves and stems. All values are dimensionless, except for $\tau_{\text {drip }}$, which is in seconds.

\begin{tabular}{|c|c|c|c|c|c|c|c|c|c|c|}
\hline & & Xleaf-up & Xleaf-lo & $\alpha_{\text {Vis-lo }}^{\text {Leaf }}$ & $\alpha_{\text {Vis-up }}^{\text {Leaf }}$ & $\alpha_{\text {NIR-lo }}^{\text {Leaf }}$ & $\alpha_{N I R-u p}^{\text {Leaf }}$ & $f_{\text {wetmax }}$ & $\tau_{\text {drip }}$ & $\tau$ \\
\hline All Reserves & DF99 & 0.00 & -0.50 & 0.062 & 0.062 & 0.60 & 0.40 & 0.25 & $7200 \mathrm{~s}$ & - \\
\hline \multirow{2}{*}{$\begin{array}{c}\text { Manaus } \\
\text { (Ducke, Cuieiras) }\end{array}$} & $\mathrm{DC}_{M}$ & 0.86 & 0.10 & 0.062 & 0.062 & 0.60 & 0.28 & 0.25 & $7200 \mathrm{~s}$ & - \\
\hline & $\mathrm{WC}_{M}$ & 0.86 & 0.10 & 0.062 & 0.062 & 0.60 & 0.28 & 0.80 & $3600 \mathrm{~s}$ & 0.10 \\
\hline \multirow[t]{2}{*}{ Jaru } & $\mathrm{DC}_{J}$ & 0.86 & 0.10 & 0.082 & 0.082 & 0.60 & 0.30 & 0.25 & $7200 \mathrm{~s}$ & - \\
\hline & $\mathrm{WC}_{J}$ & 0.86 & 0.10 & 0.082 & 0.082 & 0.60 & 0.30 & 0.80 & $3600 \mathrm{~s}$ & 0.40 \\
\hline
\end{tabular}

\section{TABLE II}

Statistics of observed and simulated surface albedos for the entire time series and for the precipitation hours at three sites in the Amazon rainforest (Cuieiras, Ducke and Jaru reserves), for the simulations based on the DF99 calibration, and for the new calibration using the dry-canopy (DC) and wet-canopy (WC) versions of the model. $\bar{X}$ is the average albedo, $\varepsilon$ is the mean relative error, and RMSE is the root mean square error.

\begin{tabular}{|c|c|c|c|c|c|c|c|c|}
\hline & & & \multicolumn{3}{|c|}{ Entire time series } & \multicolumn{3}{|c|}{ Precipitation hours } \\
\hline & & & $\bar{X}$ & $\varepsilon(\%)$ & RMSE & $\overline{\bar{X}}$ & $\varepsilon(\%)$ & RMSE \\
\hline \multirow{12}{*}{$\begin{array}{l}\text { Using set of } \\
\text { tropical parameters } \\
\text { calibrated for the } \\
\text { sites near to Manaus }\end{array}$} & \multirow{4}{*}{$\begin{array}{l}\text { Ducke } \\
\text { Reserve }\end{array}$} & DF99 & 0.146 & 23.44 & 0.0398 & 0.139 & 41.58 & 0.0550 \\
\hline & & $\mathrm{DC}_{M}$ & 0.121 & 2.14 & 0.0219 & 0.120 & 22.13 & 0.0365 \\
\hline & & $\mathrm{WC}_{M}$ & 0.118 & -0.03 & 0.0210 & 0.105 & 6.11 & 0.0302 \\
\hline & & Observed & 0.118 & - & - & 0.099 & - & - \\
\hline & \multirow{4}{*}{$\begin{array}{l}\text { Cuieiras } \\
\text { Reserve }\end{array}$} & DF99 & 0.146 & 24.11 & 0.0384 & 0.142 & 40.79 & 0.0521 \\
\hline & & $\mathrm{DC}_{M}$ & 0.121 & 2.58 & 0.0169 & 0.120 & 19.16 & 0.0320 \\
\hline & & $\mathrm{WC}_{M}$ & 0.117 & -0.73 & 0.0142 & 0.104 & 2.91 & 0.0234 \\
\hline & & Observed & 0.118 & - & - & 0.101 & - & - \\
\hline & \multirow{4}{*}{ Jaru } & DF99 & 0.146 & 12.26 & 0.0332 & 0.145 & 19.57 & 0.0387 \\
\hline & & $\mathrm{DC}_{M}$ & 0.121 & -7.15 & 0.0232 & 0.121 & -0.35 & 0.0222 \\
\hline & & $\mathrm{WC}_{M}$ & 0.117 & -9.68 & 0.0243 & 0.108 & -10.93 & 0.0247 \\
\hline & & Observed & 0.130 & - & - & 0.121 & - & - \\
\hline \multirow{4}{*}{$\begin{array}{l}\text { Using set of } \\
\text { optical parameters } \\
\text { calibrated for } \\
\text { Jaru site }\end{array}$} & \multirow{4}{*}{ Jaru } & DF99 & 0.146 & 12.26 & 0.0332 & 0.145 & 19.57 & 0.0387 \\
\hline & & $\mathrm{DC}_{J}$ & 0.133 & 1.98 & 0.0215 & 0.132 & 9.43 & 0.0250 \\
\hline & & $\mathrm{WC}_{J}$ & 0.129 & -0.50 & 0.0209 & 0.121 & 0.40 & 0.0207 \\
\hline & & Observed & 0.130 & - & - & 0.121 & - & - \\
\hline
\end{tabular}


forest (Cuieiras, Ducke and Jaru reserves), for the simulations based on the DF99 calibration, and for the new calibration using the dry-canopy (DC) and wet-canopy (WC) versions of the model.

Mean relative error $(\varepsilon)$ and root mean square error (RMSE) are defined according to Equations 5 and 6:

$$
\begin{aligned}
& \varepsilon=\frac{1}{n} \sum_{i=1}^{n} \frac{\left(X_{i}^{S}-X_{i}^{o}\right)}{X_{i}^{o}} \\
& R M S E=\sqrt{\frac{\sum_{i=1}^{n}\left(X_{i}^{S}-X_{i}^{o}\right)^{2}}{n}}
\end{aligned}
$$

where $X^{s}$ and $X^{o}$ are simulated and observed albedos, and $n$ is the number of data points. Given our interest here in the effects of canopy wetness on the simulated rainforest albedo, we analyzed the data during the "precipitation hours" apart from the entire data (Table II). For the entire time series, for the two sites near Manaus, the new calibration $\left(\mathrm{DC}_{M}\right)$ represents a considerable improvement over the DF99 calibration, lowering the mean relative error by an order of magnitude, and the RMSE by nearly half. The inclusion of the effects of canopy wetness on the radiative transfer code further reduces $\varepsilon$ and RMSE, which is consistent with the results shown in Figures 2 to 4 . The mean errors involved in the simulations are within the acceptable range for the studied sites, with RMSE being typically smaller than 0.08 (Stroeve et al. 2005). Looking for a single parameterization for Amazonia, we also tested the Manaus parameters at the Jaru site. However, it turns out that the average of the observed albedo at the Jaru site is much higher than at the Manaus sites, and the parameters used for Manaus are not suitable to Jaru. We then selected a new set of parameters for the Jaru site ( $\left.\mathrm{DC}_{J}\right)$. Results for the Jaru site, using a site-specific calibration, showed an improvement similar to the one obtained at the Manaus sites.

Although the WC simulation shows an improvement in the simulation statistics for the entire time series, its true effect is best seen in the analysis of data during the precipitation hours. Initially, we could verify that the DF99 and DC simulation results during the precipitation hours are much worse than the equivalent result for the entire time series, which by itself indicates that a precipitation-related process is missing in the model. In addition, the WC simulations for the precipitation hours improve considerably the results when compared to the control (DC), with $\varepsilon$ dropping by an order of magnitude and RMSE decreasing by about one-fifth.
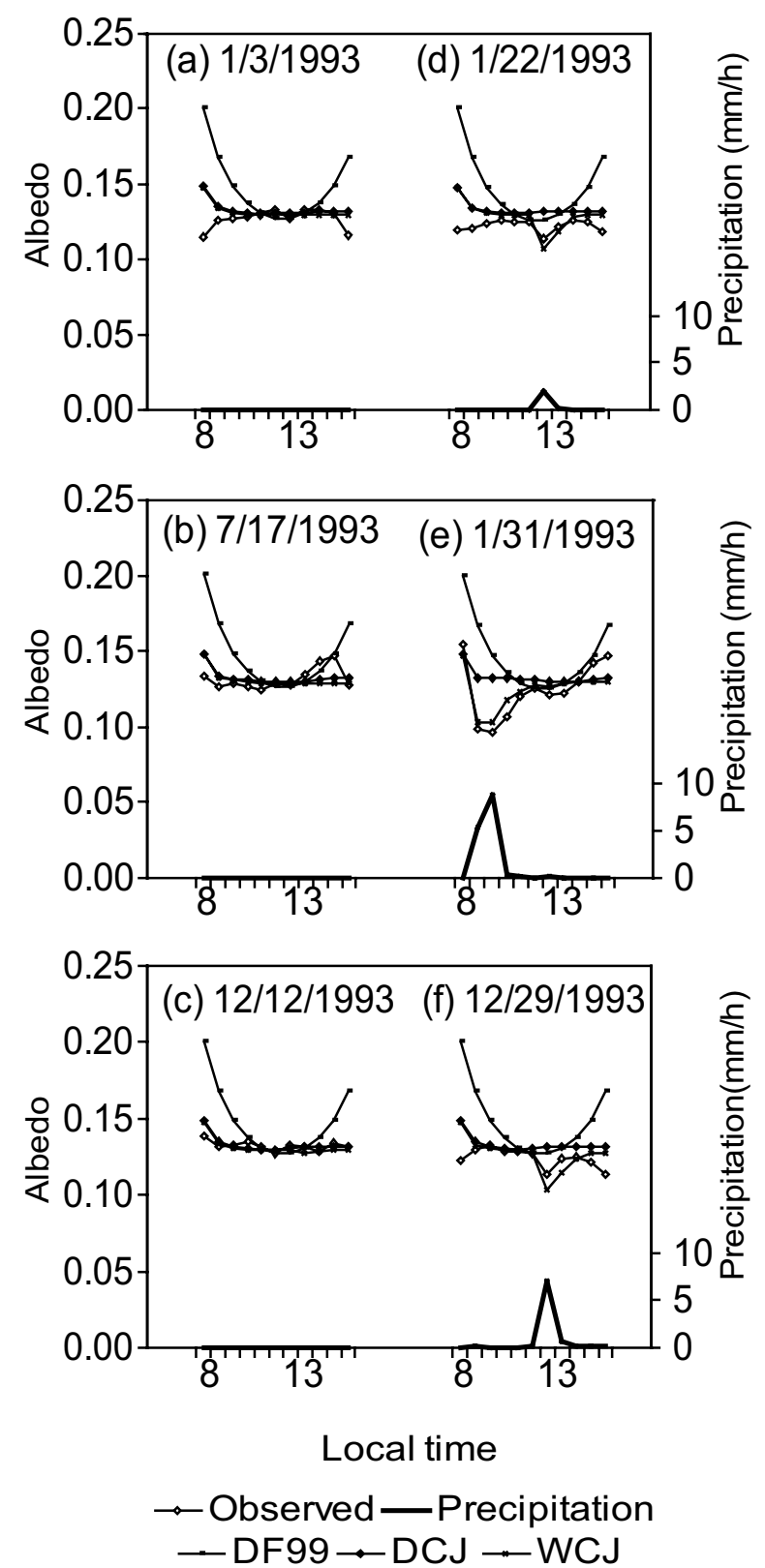

Fig. 4 - Diurnal variation of the simulated and observed surface albedo in the Jaru Reserve for the selected days.

These results demonstrate that, at the hourly time scale, the incorporation of canopy wetness on the radiative transfer calculations substantially improves the simulation results, in particular when the canopy is wet, but also brings an improvement to the simulation of the entire period. 

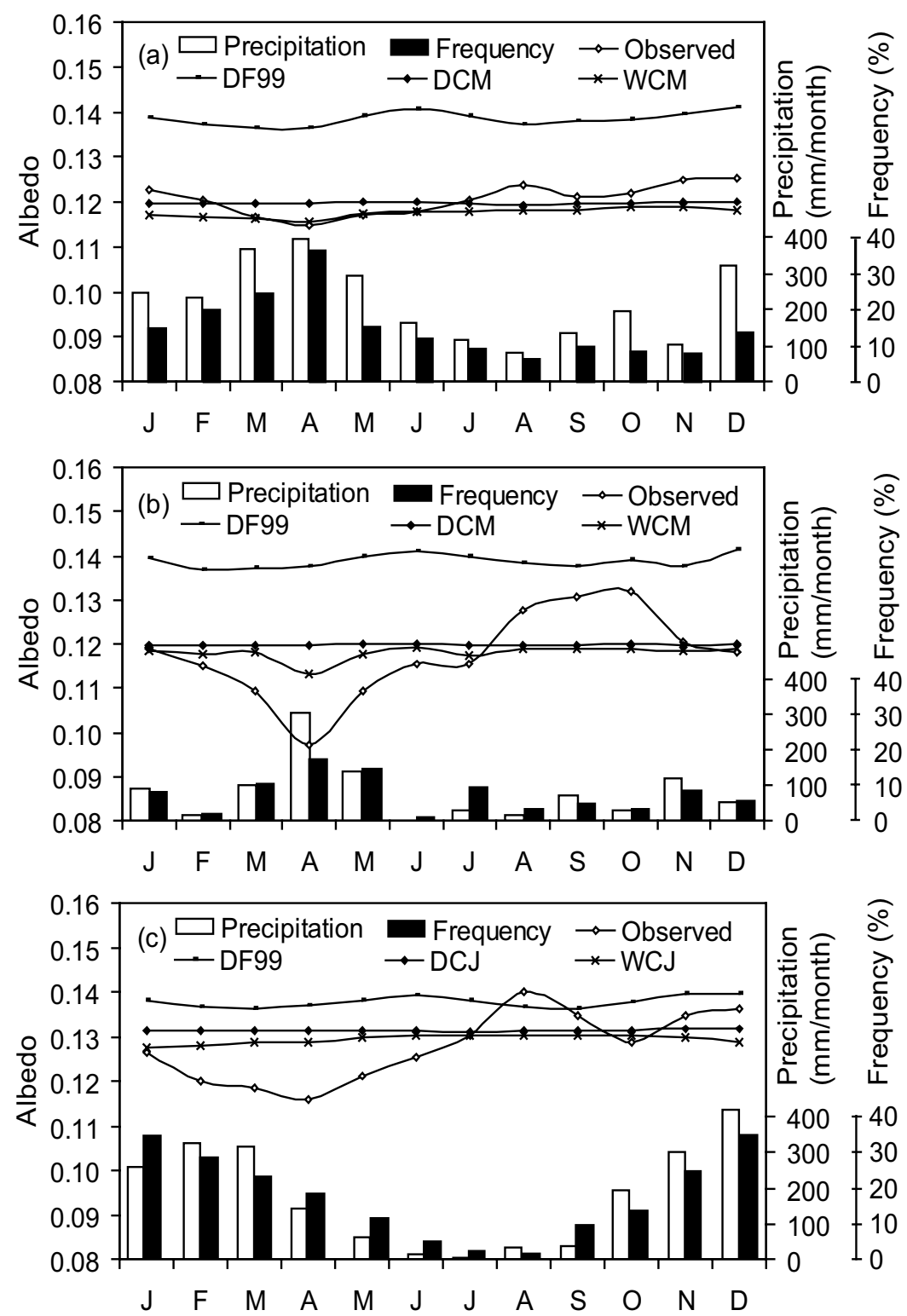

Fig. 5 - Monthly profile of the observed and simulated surface albedos, and monthly precipitation and frequency of rainfall events at three sites in the Amazon rainforest: (a) Cuieiras Reserve, from June 1999 to September 2000, (b) Ducke Reserve, from January to December 1995, and (c) Jaru Reserve, from January to December 1993.

We also compared the model results at the monthly time scale for the three sites studied (Fig. 5). In all cases, the WC albedo is smaller than the DC albedo, but the changes introduced did not substantially modify the simulated albedo. As seen in Figures 2 to 4, because of evaporation and dripping, the effect of canopy wetness on the surface albedo was restricted to the duration of a rainfall event plus one or two hours.
Although Amazonia is one of the rainiest climates on Earth, the frequency of rainfall events $(7.1 \%$ at Ducke, $14.2 \%$ at Cuieiras and $17.0 \%$ at Jaru) is relatively low for a more significative effect of canopy wetness on albedo seasonality.

An exception is observed at the Ducke Reserve (Fig. 5b), where a more pronounced drop in the WCsimulated albedo was observed in April. Even in this 
extreme case, the simulated decrease in monthly albedo accounts for less than half of the observed change, which led us to conclude that canopy wetness alone is not sufficient to represent correctly the seasonal variability of the albedo of a tropical rainforest.

\section{CONCLUSIONS}

The goal of this work is to study the effect of canopy wetness on the simulated albedo of a tropical rainforest. Simulations were run using three versions of the IBIS model: the standard version, the same version recalibrated to fit the data of albedo on tropical rainforests, and a modified version that incorporates the effects of canopy wetness on surface albedo, for three sites in the Amazon forest in both hourly and monthly time scales.

The incorporation of canopy wetness on the radiative transfer calculations improves the simulation results at the hourly time scale, reproducing the observed decrease in surface albedo during the precipitation hours, when the canopy is wet. Although the canopy wetness has an important effect, this effect is restricted to when the canopy is actually wet, which is a relatively short period of time at monthly or longer time scales. Therefore, the changes introduced are not sufficient to substantially improve the representation of albedo seasonality.

While these results exclude the role of canopy wetness as a main source of seasonal variability of the albedo on tropical rainforests, this study narrows the choice of sources of albedo seasonal variation. Following the discussion of Culf et al. (1995) and Berbet and Costa (2003) on the subject, we recommend that future studies investigate the role of photoinhibition and leaf water potential on the seasonality of the albedo on tropical rainforest. The clear definition of these roles, and their incorporation into climate models will eventually allow us to do much more detailed studies of the climatic effects of tropical deforestation.

\section{ACKNOWLEDGMENTS}

S.N.M. Yanagi was supported by Conselho Nacional de Desenvolvimento Científico e Tecnológico $(\mathrm{CNPq})$ grant to the graduate program in Agricultural Meteorology, UFV (process 142100/2003-0). M.H. Costa was also partially supported by CNPq (process 305412/2003-5).

\section{RESUMO}

A informação precisa do albedo superficial é essencial para a modelagem climática, especialmente para regiões, tais como a Amazônia, onde a resposta da circulação atmosférica regional às mudanças do albedo superficial é forte. Estudos preliminares têm indicado que os modelos ainda não são capazes de reproduzir corretamente os detalhes da variação sazonal do albedo superficial. Portanto, investigou-se o papel do molhamento foliar sobre o albedo simulado de uma floresta tropical por meio da modificação do código de transferência radiativa no dossel do IBIS para incorporar os efeitos do molhamento do dossel sobre a refletância da vegetação. Neste estudo, procederamse simulações usando três versões do modelo superfície terrestre/ecossistema IBIS: a versão padrão, a mesma versão recalibrada para ajustar aos dados de albedo de florestas tropicais e, uma versão modificada que incorpora os efeitos do molhamento do dossel sobre o albedo superficial, para três sítios da floresta amazônica em escalas horária e mensal. Os resultados demonstraram que, em escala horária, a incorporação do molhamento do dossel sobre os cálculos de transferência radiativa melhora substancialmente os resultados simulados, enquanto que, em escala mensal, essas mudanças não modificam substancialmente o albedo simulado.

Palavras-chave: molhamento do dossel, albedo diurno, floresta tropical e simulação.

\section{REFERENCES}

Berbet MLC And Costa MH. 2003. Climate change after tropical deforestation: seasonal variability of surface albedo and its effects on precipitation change. J Clim 16: 2099-2104.

BONAN GB. 1996. A Land surface model (LSM version 1.0) for ecological, hydrological, and atmospheric studies: technical description and user's guide. NCAR Technical note TN-417+STR, $150 \mathrm{p}$.

BOTTA A AND FOLEY JA. 2002. Effect of climatic variability and disturbances on the Amazonian terrestrial ecosystems dynamics. Global Biogeochem Cycles 16: 1-11.

Costa MH and Foley JA. 2000. Combined effects of deforestation and doubled atmospheric $\mathrm{CO}_{2}$ concentrations on the climate of Amazonia. J Clim 13: 18-34.

CUlf AD, Fisch G And Hodnett MG. 1995. The albedo of Amazonian forest and ranch land. J Clim 8: 1544-1554.

DELIRE C AND Foley JA. 1999. Evaluating the performance of a land surface/ecosystem model with biophys- 
ical measurements from contrasting environments. J Geophys Res 104: 16895-16909.

DIRMEYER PA AND SHUKLA J. 1994. Albedo as a modulator of climate response to tropical deforestation. J Geophys Res 99: 863-20, 877.

Foley JA, Botta A, Coe MT and Costa MH. 2002. El Niño-Southern Oscillation and the climate, ecosystems and rivers of Amazonia. Global Biogeochem Cycles 16: 79-1, 79-20.

Foley JA, Prentice iC, Ramankutty N, Levis S, Pollard D, Sitch S And Haxeltine A. 1996. An integrated biosphere model of land surface processes, terrestrial carbon balance and vegetation dynamics. Global Biogeochem Cycles 10: 603-628.

Kucharik CJ, Foley JA, Delire C, Fisher VA, Coe MT, Gower ST, Lenters JD, Young-Molling C, Norman JM And RAmankUtTy N. 2000. Testing the performance of a dynamic global ecosystem model: Water balance, carbon balance and vegetation structure. Global Biogeochem Cycles 14: 795-825.

Nobre C, Sellers P And Shukla J. 1991. Amazonian deforestation and regional climate change. J Clim 4: 957988 .
Norman JM AND JARVIS PG. 1975. Photosynthesis in Sitka Spruce [Picea sitchensis (Bong.) Carr.]. V. Radiation penetration theory and a test case. J Appl Ecol 12: 839878.

OLESON KW ET AL. 2004. Technical description of the Community Land Model (CLM). NCAR Technical note TN-461+STR, 174 p.

Pollard D And ThOmpson S. 1995. The effect of doubling stomatal resistance in a global climate model. Global Planate Change 10: 129-161.

Rowe CM. 1991. Modeling land-surface albedos from vegetation canopy architecture. Phys Geography 12(2): 93114.

SEllers PJ. 1985. Canopy reflectance, photosynthesis and transpiration. Int J Remote Sens 6: 1335-1372.

Sellers PJ, Mintz Y, Sud Y And Dalcher A. 1986. A simple biosphere model $(\mathrm{SiB})$ for use within general circulation models. J Atm Sci 43: 505-531.

Stroeve J, Box JE, Gao F, Liang S, Nolin A AND SchAAF C. 2005. Accuracy assessment of the MODIS 16-day albedo product for snow: comparisons with Greenland in situ measurements. Remote Sens Environ 94: 46-60. 